\title{
Characterization of charcoal and firewood ash for use in African peri-urban agriculture
}

\author{
Dora Neina ${ }^{1,2} \mathbb{0}$, Sibylle Faust ${ }^{2}$ and Rainer Georg Joergensen ${ }^{2^{*}}$
}

\begin{abstract}
Background: Ample quantities of ashes generated from domestic biomass energy combustion in Ghanaian kitchens are currently disposed of despite their potential agricultural value. This study aimed to investigate the potential agricultural value of charcoal and firewood ashes in terms of differences in the chemical and mineralogical compositions, and to identify the suitability of aqua regia, $\mathrm{H}_{2} \mathrm{SO}_{4}$, vinegar and distilled water to extract plant nutrients $(\mathrm{Ca}, \mathrm{Mg}, \mathrm{K}, \mathrm{Na}$, and $\mathrm{P}$ ). The chemical compositions were determined by atomic absorption spectrometry after extractions with aqua regia, $\mathrm{H}_{2} \mathrm{SO}_{4}$, vinegar and distilled water while mineralogy was determined by $X$-ray powder diffraction.

Results: The charcoal ash had 0.2 units, $13 \mathrm{ds} \mathrm{m}^{-1}$, and $7 \%$ higher $(P<0.05) \mathrm{pH}, \mathrm{EC}$, and CCE, respectively, than the firewood ash, whereas the latter had 6, 17, 43, and $139 \mathrm{\mu g} \mathrm{g}^{-1}$ higher $(P<0.05) \mathrm{As}, \mathrm{Cu}, \mathrm{Mg}$, and Zn contents, respectively, and more minerals with $86 \%$ being $\mathrm{Mg}$-rich. Calcite and calcium oxide were the dominant minerals occurring in both ashes followed by calcium manganate $\left(\mathrm{CaMnO}_{3}\right)$. Aqua regia and vinegar were suitable for $\mathrm{Ca}$, acidic solutions for $\mathrm{Mg}, \mathrm{H}_{2} \mathrm{SO}_{4}$ and aqua regia for $\mathrm{P}$ with $\mathrm{Na}$ and $\mathrm{K}$ being virtually soluble in all solutions. Lead, $\mathrm{Mn}, \mathrm{Ni}$, and $\mathrm{Zn}$ had values in the order of hundreds.

Conclusions: Although the ashes differ, they both contain trace elements whose bioavailability may differ and may not necessarily lead to plant uptake after field application. This offers an opportunity for further research into the threshold trace element contents of wood ash and their relationship with plant uptake in different soil pH and soil types.
\end{abstract}

Keywords: Calcium carbonate equivalence, Electrical conductivity, Solid waste, Trace elements, X-ray diffraction

\section{Background}

Wood ash is a waste product of biomass combustion, but it contains substantial amounts of plant nutrients such as calcium $(\mathrm{Ca})$, potassium $(\mathrm{K})$, magnesium $(\mathrm{Mg})$, and phosphorus (P) [1-3]. This composition of wood ash makes it a valuable fertilizer to increase the yields of crop and forest products $[1,4,5]$. Previous studies revealed that wood ash has an acid-neutralizing capacity, expressed as calcium carbonate equivalence (CCE), in the range of $17-95 \%[6,7]$. The actual chemical composition of wood ash depends on the type and source of the biomass,

\footnotetext{
*Correspondence: joerge@uni-kassel.de

2 Soil Biology and Plant Nutrition, University of Kassel, Nordbahnhofstr. 1a,

37213 Witzenhausen, Germany

Full list of author information is available at the end of the article
}

combustion type and temperature used for its production $[4,8,9]$.

Beside its acid-neutralizing capacity and fertilizer value, wood ash may also increase the basic cation contents and the effective CEC of some soils $[3,10]$. Due to the variable composition of wood ash, a random application rate to a particular soil may be injurious to both soil and crop health as a result of shocks caused by sudden $\mathrm{pH}$ increase. For instance, at an application rate of $25 \mathrm{~g} \mathrm{~kg} \mathrm{soil}^{-1}$, Nabeela et al. [5] found detrimental effects on Brassica napus L. compared with lower rates of 1 and $10 \mathrm{~g} \mathrm{~kg} \mathrm{soil}{ }^{-1}$, suggesting possible plant-specific responses to the application of ash. Wood ash reacts faster than regular liming materials because of the finer 
particles and leads to high initial $\mathrm{pH}$ increases that seldom last [2].

Major nutrient elements in ash exist in different crystalline forms, which have different solubility in different extraction solutions [11]. Therefore, different extraction solutions were tested. Vinegar as non-traditional extraction solution was included to test its efficacy to extract the major nutrient elements in case poor farmers are not able to access regular acids. The mineral composition of the ashes was examined to differentiate their various crystalline forms and associations.

Wood ash contains substantial but variable amounts of trace elements, particularly, $\mathrm{Cd}, \mathrm{Cu}, \mathrm{Pb}$, and $\mathrm{Zn}[1,2]$ and may also contain some polycyclic aromatic hydrocarbons $[12,13]$ that may limit its use as a plant nutrient and pose hazards to the environment. However, the total quantities of the trace elements may not necessarily translate into bioavailable forms due to differences in solubility, which may be influenced by rhizosphere and soil factors. For instance, high amounts of $\mathrm{Cd}, \mathrm{Cr}, \mathrm{Cu}, \mathrm{Mn}, \mathrm{Pb}$, and $\mathrm{Zn}$ were found in sewage sludge ash [14], which did not accumulate in the edible parts of oats (Avena sativa L.) and rapeseed (Brassica napus L.) after application. Conversely, other studies have shown that plants take up trace elements through applied wood ash [5]. In this case, plant and soil conditions may have played a role in metal accumulation.

Biomass energy has been the major source of domestic energy in the past. Until now, over $80 \%$ of the population in sub-Saharan Africa still depends on biomass energy [15]. Cross-sectional time series data for 20 countries of sub-Sahara Africa reveal that wood fuel accounts for $70 \%$ of energy consumption [16]. In Ghana, $90 \%$ of rural households depend on firewood for cooking compared to $61 \%$ charcoal use by urban residents [17]. The share of biomass to the primary energy supply was $36.9 \%$ in 2018 [18]. Apart from domestic use, local eateries also use huge amounts of biomass fuel in Ghana [17]. Although the Ghana Government discouraged biomass fuel use by promoting the use of liquefied petroleum gas (LPG) in the past decade. Unfortunately, such efforts have fallen short of sustainability due to recurrent shortages and price hikes of LPG [19]. During these times, many urban residents resort to cheap options such as charcoal [17]. The Strategic National Energy Plan 2006-2020 of the Ghana Energy Commission estimates that the use of biomass fuel is expected to increase alongside non-biomass fuel due to rising populations [17]. During the last 10 years, the supply of woodfuels for charcoal and firewood was increasing [18].

It is obvious that biomass energy use in Ghana may persist for decades [19] and continuously generate ash, which constitutes a substantial fraction of municipal solid waste disposed in poorly organized waste dumps. The fertilizer value of ash could be harnessed and utilized in the Ghanaian agricultural system, particularly in urban and peri-urban agriculture (UPA) where it could improve crop yields, enhance the livelihoods of poor UPA farmers and enhance urban food security in Ghana. UPA is a vital livelihood strategy in sub-Saharan Africa (SSA), employing over $10 \%$ of the population [20]. In Ghana, UPA employs about 800-1000 farmers in Accra alone where it improves urban food security and alleviates poverty [21]. However, soil nutrient mining caused by continuous cultivation without substantial nutrient enrichment is one of the challenges of UPA in Ghana [21]. Wood ash could be used to supplement the existing but limited fertilizer sources used by UPA famers. Due to large and frequent biomass fuel use by the eateries, large amounts of wood ash are expected to be produced within short intervals compared to households. The nutrient content of wood ash makes it a potential source of cheap fertilizer to supplement the prevalent poultry manure used in UPA in Ghana [21] and increase food security.

Many studies exist on industrial wood ash comprising mostly fly and bottom ash or coal ash [9, 22]. Studies characterizing wood ash generated from the combustion of firewood on the one hand and that of charcoal on the other hand are scarce. While ash from charcoal is a product of slow pyrolysis under anoxic conditions and followed by combustion under oxic conditions, firewood, on the other hand, is a product of direct combustion of wood under oxic conditions. Further, some constituents are likely to volatilize along with the formation of other minerals in the ashes owing to the influence of temperature, there is bound to be differences in their compositions. The aims of this study were to (i) investigate the differences in the chemical and mineralogical compositions; and (ii) identify the suitability of aqua regia, $\mathrm{H}_{2} \mathrm{SO}_{4}$, vinegar and distilled water to extract plant nutrients $(\mathrm{Ca}$, $\mathrm{Mg}, \mathrm{K}, \mathrm{Na}$, and $\mathrm{P}$ ). The ultimate goal was to characterize the ashes produced from local kitchens for properties that are critical for their potential utilization in UPA. The underlying hypothesis is that charcoal and firewood ashes are both highly suitable as fertilizers UPA in terms of their nutrient contents without threat of containing excessive toxic trace elements.

\section{Material and methods}

\section{Study sites and sampling}

The ash samples were collected from kitchens from five regional capital cities in southern Ghana namely, Accra (Greater Accra Region), Cape Coast (Central Region), Ho (Volta Region), Koforidua (Eastern Region) and 


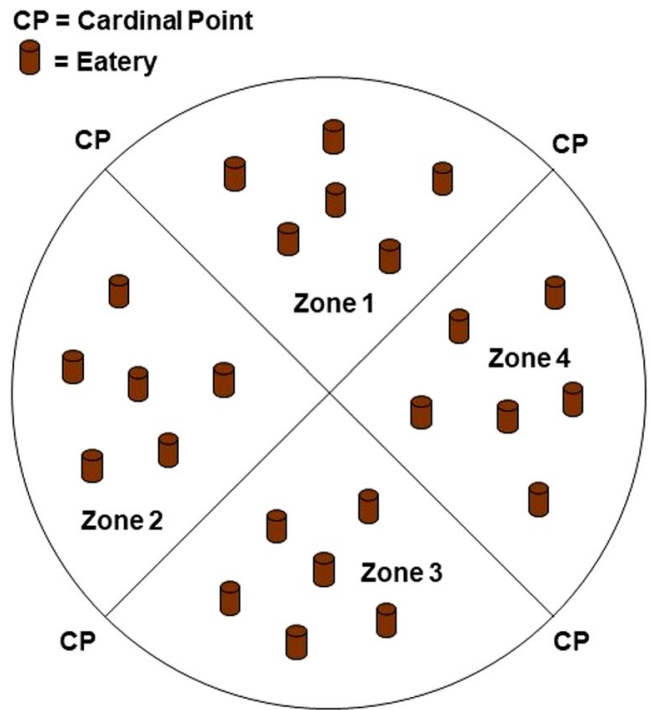

Fig. 1 A representation of the "false cardinal points" used to define the four hypothetical segments for each city

Sekondi-Takoradi (Western Region). Most of the charcoal used in the urban areas originates from the hinterlands, particularly from the forest, transitional and savannah ecological zones of Ghana. The firewood used in most cities rather comes from "regular firewood" with and without wood bark such as timber wastes, from bamboo or wood wastes from construction sites. The kitchens comprised food vendors, eateries, and some secondary schools. The "false cardinal points" were defined using major roads that cross each other near or around each city center to form four hypothetical segments (Fig. 1). Each of these segments represented a zone making four zones per city within which the ashes were sampled. This approach was adopted with the assumption that the nature of settlements differs with the city and that most eateries and food vendors follow traffic flow, which also has a bearing on demand for food. This was however not applicable to the schools. In each city, six sacks lined with plastic bags were left each zone for charcoal and firewood ashes except for Accra where eight sacks were left to avoid having many missing samples. This is because the hassles of life in Accra could restrain people from commitments such as ash sampling and safekeeping for days. The sacks were retrieved after a week and transported to the University of Ghana, main campus for further processing. The dominant color of the ashes was light grey. The charcoal ash comprised a few greyish and greyish olive colors while the firewood ash was mainly greyish olive. Light grey is a common color of most ashes, although a few greyish and greyish olive colors exist. This seems to depend on the type of biomass. For instance, ashes from Parkia biglobosa (Jacq.) R. Br. ex G. Don. (African locust bean) and Vitellaria paradoxa G. Don (shea tree) often have light grey colors while those of many eucalyptus species is greyish olive (Neina, unpublished data).

\section{Ash $\mathrm{pH}$, electrical conductivity, and calcium carbonate equivalence}

The samples were composited, passed through a 1-mm sieve and kept for laboratory analysis. The electrical conductivity (EC) and $\mathrm{pH}$ of the ash were measured in 1:5 ash-water ratio using a multi-parameter $\mathrm{pH} / \mathrm{EC}$ meter (PL-700AL, Gondo Electronics, Taiwan) after shaking for $30 \mathrm{~min}$ and leaving to stand for $1 \mathrm{~h}$. The CCE was determined by digesting ash $(<1 \mathrm{~mm})$ with $1 \mathrm{~mol} \mathrm{~L}^{-1} \mathrm{HCl}[6$, 14,23 ]. Ash $(1 \mathrm{~g})$ was weighed into $100 \mathrm{~mL}$ conical flasks, $50 \mathrm{~mL}$ of $1 \mathrm{~mol} \mathrm{~L}^{-1} \mathrm{HCl}$ were added, shaken and left overnight. The digest was homogenized on a magnetic stirrer and filtered. Afterwards, $10 \mathrm{~mL}$ of the filtrate was pipetted into a 50-mL conical flask, diluted with $10 \mathrm{~mL}$ distilled water. Three drops of methyl red indicator were added and titrated with $0.5 \mathrm{~mol} \mathrm{~L}^{-1} \mathrm{NaOH}$ solution to a pH 7 endpoint. Four blanks (i.e., $1 \mathrm{~mol} \mathrm{~L}^{-1} \mathrm{HCl}$ solution without ash) were included and treated in a similar manner. The CCE was calculated using the equation:

$$
\operatorname{CCE}(\%)=((a-b) / S) \times 2 M \times 100,
$$

where $a$ is $\mathrm{mL} \mathrm{NaOH}$ used for blank titrations; $b$ is $\mathrm{mL}$ $\mathrm{NaOH}$ used for titration of the soil sample; $S$ is weight of oven-dried ash (g); $M$ is concentration of $\mathrm{NaOH}$ solution $\left(\mathrm{mol} \mathrm{L}^{-1}\right)$.

\section{Analysis of nutrient elements and trace element contents} Analysis of plant nutrient elements was carried out using an atomic absorption spectrometer, a mercury analyzer and a spectrophotometer after extraction with aqua regia $\left(10.5 \mathrm{~mL} \mathrm{37 \%} \mathrm{HCl}, 3.5 \mathrm{~mL} 69 \% \mathrm{HNO}_{3}\right)$, concentrated $\mathrm{H}_{2} \mathrm{SO}_{4}$, vinegar (spirit vinegar, NCP Alcohols, Durban, South Africa) and distilled water. For the acid extractions solutions, $500 \mathrm{mg}$ of the fine fractions (1 $\mathrm{mm})$ was mixed with the solutions and allowed to stand overnight. Afterwards, distilled water was added to the mixture and allowed to boil over a magnetic stirrer for $5 \mathrm{~min}$. The suspension was filtered using 150$\mathrm{mm}$ qualitative filter paper (Grade 413 filter paper, qualitative; VWR International) and measured for the target constituents. Four replicates of $50 \mathrm{mg}$ of BCR038 coal fly ash reference materials (Institute for Reference Materials and Measurements, Joint Research Centre, European Commission) was included and treated in a similar manner for internal checks. Water 
extracts were obtained by shaking $500 \mathrm{mg}$ of ash in $30 \mathrm{~mL}$ distilled water and filtered.

Total nutrient elements $(\mathrm{Ca}, \mathrm{Mg}, \mathrm{K}$, and $\mathrm{Na})$ and trace element contents $(\mathrm{Cd}, \mathrm{Cu}, \mathrm{Mn}, \mathrm{Pb}$, and $\mathrm{Zn})$ were measured using an Atomic Absorption Spectrometer (AAS) (Perkin Elmer AAnalyst 800, Germany) while As and $\mathrm{Ni}$ were detected on a PinAAcle 900T Atomic Absorption Spectrometer (Perkin Elmer). Total trace element contents were measured only in the aqua regia extracts. For mercury $(\mathrm{Hg})$ analysis, the dry ash samples were subjected to Solid Thermal Decomposition Atomic Absorption Spectrophotometry (EPA7473) using a DMA-80 Tri-cell direct mercury analyzer (Milestone, Sorisole, Italy). The content of total phosphorus was measured at $710 \mathrm{~nm}$ on a UV/VIS spectrophotometer (Pharo 300 Spectroquant, Merck Millipore, Darmstadt, Germany) after coloration of the extracts with ammonium molybdate and ascorbic acid. In each batch of analysis, four replicates of blank samples were included, which were treated in the same way, but without ash sample.

\section{Mineralogical analysis}

Ash samples were subsampled, homogenized and passed through $47 \mu \mathrm{m}$ before mineralogical analysis by X-ray powder diffraction (XRD). The XRD was performed at the Department of Physics, University of Ghana with the aid of a Philips PANalytical Empyrean Series 2 X-Ray Diffractometer (Almelo, The Netherlands). The scan parameters were $45 \mathrm{kV}$ and $40 \mathrm{~mA}$, having a $\mathrm{Cu}-\mathrm{K} \alpha$ radiation and a graphite monochromator. The scan was a continuous type at a speed of $1 \mathrm{~s}$ per $0.03^{\circ} 2$-Theta starting from $5.0150^{\circ} 2$-Theta and ending at $69.9650^{\circ} 2$-Theta. The XRD patterns were collected using PANalytical Xpert Data Collector and analyzed with PANalytical HighScore Plus $\mathrm{V}$ 3.0.5. Identification of minerals was done with reference data from PANalytical HighScore PDF-2.

\section{Statistical analysis}

The data were checked for conformity to the criteria of analysis of variance (ANOVA). Only three zones of Cape Coast charcoal ash samples were retrieved. Therefore, we substituted the missing value with the mean of the three values plus the standard deviation (mean of $N=3+\mathrm{SD}$ ) for the purpose of statistics. Where the criteria of ANOVA were not met, the data were either logor square root-transformed, and the level of significance was set at 5\%. Two-way ANOVA was used to analyze the data using the ash type and city as the independent factors. The means from ANOVA were separated using the Holm-Sidak post hoc test. The interrelationships between extracted elements were tested by Pearson correlation analysis. Statistical analyses were performed using SPSS version 20 (IBM-SPSS, USA) and Sigma Plot 13 (Systat Software, USA).

\section{Results}

Ash pH, electrical conductivity, and calcium carbonate equivalence

The charcoal ash had a slightly more alkaline $\mathrm{pH}$, a higher $\mathrm{EC}$ and CCE. Specifically, the mean $\mathrm{pH}$ of charcoal ash was $0.2 \mathrm{pH}$ units higher $(P=0.02)$ than the firewood ash (Table 1) and showed almost no variation among cities. The mean EC of the charcoal ash was also $13 \mathrm{dS} \mathrm{m}^{-1}$ higher $(P=0.01)$ than the firewood ash, showing differences among the cities $(P=0.04)$. Further, the mean CCE of the charcoal ash was $7 \%$ higher $(P<0.01)$ than that of the firewood and differed $(P=0.02)$ among the cities.

\section{Elemental composition}

The trace element (As, $\mathrm{Cd}, \mathrm{Cu}, \mathrm{Hg}, \mathrm{Mn}, \mathrm{Ni}, \mathrm{Pb}$, and $\mathrm{Zn}$ ) contents in both ash types (Table 1) as extracted from the aqua regia varied widely among the samples both within and between the cities. On the average, the elements were present in the order $\mathrm{Pb}>\mathrm{Mn}>$ $\mathrm{Ni}>\mathrm{Zn}>\mathrm{Cu}>\mathrm{Cd}>\mathrm{As}>\mathrm{Hg}$ for charcoal ash, whereas that of firewood was $\mathrm{Pb}>\mathrm{Mn}>\mathrm{Zn}>\mathrm{Ni}>\mathrm{Cu}>\mathrm{As}>\mathrm{Cd}>$ $\mathrm{Hg}$ (Table 1). Lead, $\mathrm{Mn}, \mathrm{Ni}$, and $\mathrm{Zn}$ had values in the order of hundreds. The ANOVA revealed interaction effects $(P<0.05)$ of ash type and city for $\mathrm{Cd}, \mathrm{Ni}$, and $\mathrm{Pb}$ contents as well as significantly higher $(P<0.05)$ contents of $\mathrm{As}, \mathrm{Cu}$, and $\mathrm{Zn}$ (Fig. 2a) in the firewood ash than in the charcoal ash. The rest of the trace elements $(\mathrm{Cd}, \mathrm{Hg}, \mathrm{Mn}, \mathrm{Ni}$, and $\mathrm{Pb})$ in both ashes did not differ significantly. Manganese and $\mathrm{Zn}$ contents were 43 and $139 \mu \mathrm{g} \mathrm{g}^{-1}$ higher in the firewood ash than in the charcoal ash, respectively, but with no statistical significance for $\mathrm{Mn}$. In contrast, $\mathrm{Ni}$ and $\mathrm{Pb}$ were 64 and $180 \mu \mathrm{g} \mathrm{g}^{-1}$ higher in the charcoal ash (Table 1) with no statistical significance.

The amounts of the elements extracted using the solutions varied depending on the elements with all of them being less water-soluble (Table 2). For $\mathrm{Ca}$, the amount of elements extracted was in the order vinegar $>$ aqua regia $>\mathrm{H}_{2} \mathrm{SO}_{4}>$ water; aqua regia $>\mathrm{H}_{2} \mathrm{SO}_{4}>$ vinegar $>$ water for Mg; vinegar $>\mathrm{H}_{2} \mathrm{SO}_{4}>$ aqua regia $>$ water for $\mathrm{K} ; \mathrm{H}_{2} \mathrm{SO}_{4}>$ vinegar $>$ aqua regia > water for $\mathrm{Na}$; and aqua regia $>\mathrm{H}_{2} \mathrm{SO}_{4}>$ vinegar $>$ water for $\mathrm{P}$. The elements extracted generally occurred in the order $\mathrm{Ca}>\mathrm{K}>\mathrm{Mg}>\mathrm{Na}>\mathrm{P}$. The Mg contents extracted by the acid extraction solutions revealed that the firewood ash contained about $20 \%$ more $\mathrm{Mg}(P<0.05)$ than the charcoal ash. Only $0.4 \%$ of the total $\mathrm{Mg}$ extracted by the acid solutions was soluble in water. The charcoal ash 
Table $1 \mathrm{Mean} \mathrm{pH}$, electrical conductivity (EC), and $\mathrm{CaCO}_{3}$ equivalence (CCE) in charcoal and firewood ash from five cities in southern Ghana as well as concentration of trace elements; probability values of a two-way ANOVA using ash type and city as factors

\begin{tabular}{|c|c|c|c|c|c|c|c|}
\hline & Charcoal & Firewood & SD & Probabilit & & & CV \\
\hline & & & & Ash type & City & Ash type $x$ city & \\
\hline $\mathrm{pH}-\mathrm{H}_{2} \mathrm{O}$ & 13.0 & 12.8 & 0.3 & 0.02 & NS & NS & 2.0 \\
\hline$E C_{1: 5}\left(d S m^{-1}\right)$ & 46 & 33 & 14 & 0.01 & 0.04 & NS & 29 \\
\hline CCE (\%) & 52 & 45 & 7 & $<0.01$ & 0.02 & NS & 12 \\
\hline As $\left(\mu g^{-1}\right)$ & 1.7 & 7.7 & 8.0 & 0.03 & NS & NS & 167 \\
\hline $\mathrm{Cd}\left(\mu \mathrm{g} \mathrm{g}^{-1}\right)$ & 3.1 & 4.1 & 2.0 & NS & NS & 0.03 & 55 \\
\hline $\mathrm{Cu}\left(\mu \mathrm{g} \mathrm{g} \mathrm{g}^{-1}\right)$ & 48 & 65 & 26 & 0.04 & 0.04 & NS & 47 \\
\hline$M n\left(\mu g g^{-1}\right)$ & 645 & 688 & 374 & NS & $<0.01$ & NS & 56 \\
\hline $\mathrm{Hg}\left(\mathrm{ng} \mathrm{g}^{-1}\right)$ & 1.8 & 1.0 & 1.7 & NS & NS & NS & 121 \\
\hline $\mathrm{Ni}\left(\mu \mathrm{g} \mathrm{g}^{-1}\right)$ & 317 & 253 & 167 & NS & NS & 0.01 & 60 \\
\hline $\mathrm{Pb}\left(\mu \mathrm{g} \mathrm{g}^{-1}\right)$ & 1310 & 1130 & 720 & NS & NS & 0.02 & 58 \\
\hline $\mathrm{Zn}\left(\mu \mathrm{g} \mathrm{g}^{-1}\right)$ & 218 & 357 & 196 & 0.01 & $<0.01$ & NS & 68 \\
\hline
\end{tabular}

$\mathrm{SD}=$ standard deviation of the whole sample group $(n=40) ; C V=$ pooled coefficient of variation between replicate samples $(n=4)$

NS not significant
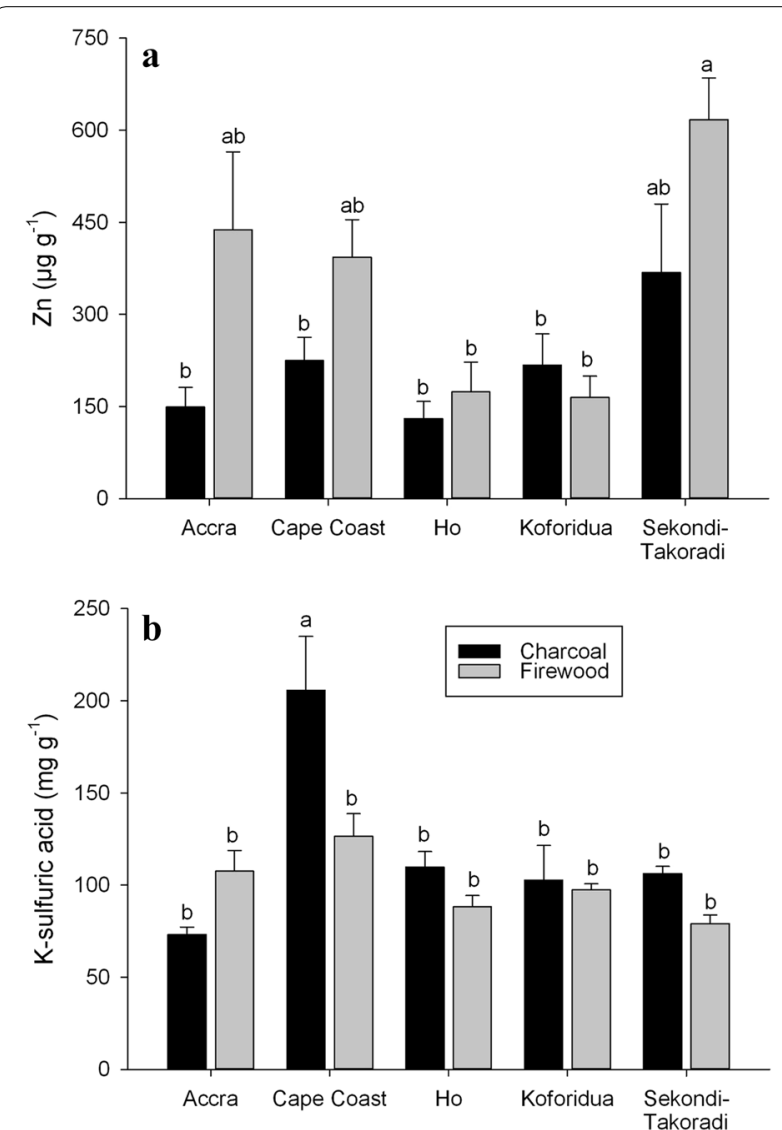

Fig. 2 a Mean concentrations of $\mathrm{Zn}$ and $\mathbf{b} \mathrm{H}_{2} \mathrm{SO}_{4}$-extractable $\mathrm{K}$ in charcoal and firewood ash from five cities in southern Ghana; bars $=$ one standard error of mean $(n=4)$; different letters on top of a bar indicate a significant difference (Holm-Sidak test, $P<0.05)$ appeared to have more $\mathrm{K}$ than the firewood ash in that vinegar and $\mathrm{H}_{2} \mathrm{SO}_{4}$ extracted 49 and $20 \mathrm{mg} \mathrm{g}^{-1}$ more $\mathrm{K}(P<0.05)$ in the charcoal ash, respectively, and varied among cities (Table 2). The $\mathrm{K}$ extracted by $\mathrm{H}_{2} \mathrm{SO}_{4}$ showed interaction effects $(P<0.01)$ of ash type and city whereby the highest and lowest $\mathrm{K}$ were found in the Cape Coast and Accra charcoal ashes (Fig. 2b), respectively. The correlation matrix revealed significant positive relations between $\mathrm{K}$ extracted by all solutions (Table 3). Sodium extracted using aqua regia and water showed interaction effects $(P<0.05)$ of ash type and city and varied among cities $(P<0.05)$ (Table 2). The $\mathrm{H}_{2} \mathrm{SO}_{4}$ and vinegar extracted over twofold the $\mathrm{Na}$ contents extracted by aqua regia and water.

Total $\mathrm{P}$ was sparingly soluble in vinegar and water compared to aqua regia and $\mathrm{H}_{2} \mathrm{SO}_{4}$ (Table 2). However, the charcoal ash $\mathrm{P}$ extracted using vinegar was 1.5 -fold higher $(P<0.01)$ than its counterpart. The water-soluble $\mathrm{P}$ was only about $0.5-1 \%$ of the total P extracted by the acid solutions. P-water did not correlate with P extracted by the three acidic solutions, whereas the latter correlated with each other (Table 3).

\section{Mineralogical composition}

The XRD showed that almost all the crystalline minerals present in both ashes were predominantly $\mathrm{Ca}$ minerals mostly occurring in association with $\mathrm{CO}_{3}, \mathrm{Fe}, \mathrm{Mg}$, $\mathrm{Mn}$, and $\mathrm{P}$ (Table 4). Calcite $\left(\mathrm{CaCO}_{3}\right)$ and calcium oxide $(\mathrm{CaO})$ were the most prevalent minerals occurring in both ashes followed by calcium manganate $\left(\mathrm{CaMnO}_{3}\right)$. Manganese-containing minerals occurred in ten cases while Mg minerals occurred in eight cases. The rest of 
Table 2 Mean concentration of nutrient elements extracted with aqua regia, $\mathrm{H}_{2} \mathrm{SO}_{4}$, vinegar, and water in charcoal and firewood ash from five cities in southern Ghana; probability values of a two-way ANOVA using ash type and city as factors

\begin{tabular}{|c|c|c|c|c|c|c|c|}
\hline & Charcoal & Firewood & SD & Probabilit & & & CV \\
\hline & $\left(\mathrm{mg} \mathrm{g}^{-1}\right)$ & & & Ash type & City & Ash type $x$ city & \\
\hline Ca-aqua regia & 131 & 120 & 26 & NS & 0.01 & NS & 16 \\
\hline $\mathrm{Ca}-\mathrm{H}_{2} \mathrm{SO}_{4}$ & 70 & 66 & 36 & NS & NS & NS & 45 \\
\hline Ca-vinegar & 164 & 148 & 38 & NS & 0.02 & NS & 18 \\
\hline Ca-water & 6.4 & 7.2 & 1.6 & NS & NS & NS & 22 \\
\hline Mg-aqua regia & 16.8 & 21.6 & 6.5 & 0.01 & 0.01 & NS & 25 \\
\hline $\mathrm{Mg}-\mathrm{H}_{2} \mathrm{SO}_{4}$ & 15.9 & 20.2 & 6.1 & 0.02 & 0.04 & NS & 25 \\
\hline Mg-vinegar & 14.2 & 18.7 & 7.4 & 0.04 & NS & NS & 31 \\
\hline Mg-water & 0.06 & 0.08 & 0.04 & NS & NS & NS & 34 \\
\hline K-aqua regia & 73 & 69 & 22 & NS & 0.01 & NS & 26 \\
\hline $\mathrm{K}-\mathrm{H}_{2} \mathrm{SO}_{4}$ & 120 & 100 & 38 & 0.02 & $<0.01$ & $<0.01$ & 17 \\
\hline K-vinegar & 136 & 87 & 74 & 0.02 & 0.02 & NS & 37 \\
\hline K-water & 24 & 24 & 3 & NS & 0.05 & 0.03 & 8 \\
\hline $\mathrm{Na}$-aqua regia & 3.9 & 4.2 & 2.7 & NS & $<0.01$ & 0.05 & 49 \\
\hline $\mathrm{Na}-\mathrm{H}_{2} \mathrm{SO}_{4}$ & 10.8 & 12.3 & 3.2 & NS & 0.01 & NS & 23 \\
\hline $\mathrm{Na-vinegar}$ & 10.1 & 11.5 & 4.3 & NS & $<0.01$ & NS & 21 \\
\hline Na-water & 3.8 & 4.4 & 1.7 & NS & 0.01 & 0.04 & 31 \\
\hline P-aqua regia & 0.45 & 0.43 & 0.13 & NS & NS & NS & 29 \\
\hline $\mathrm{P}-\mathrm{H}_{2} \mathrm{SO}_{4}$ & 0.42 & 0.38 & 0.12 & NS & NS & NS & 31 \\
\hline P-vinegar & 0.20 & 0.13 & 0.06 & $<0.01$ & NS & NS & 39 \\
\hline P-water & 0.002 & 0.002 & 0.001 & NS & NS & NS & 59 \\
\hline
\end{tabular}

$\mathrm{SD}=$ standard deviation of the whole sample group $(n=40) ; \mathrm{CV}=$ pooled coefficient of variation between replicate samples $(n=4)$

NS not significant

the minerals occurred in about $20 \%$ in the ashes. The firewood ash had more minerals than the charcoal ash. Aluminum and silicon oxides were also present in the firewood ash and could be associated with the sand particles found in the traditional cooking stoves or hearths.

\section{Discussion}

\section{Ash pH, electrical conductivity, and calcium carbonate equivalence}

Charcoal and firewood ashes differ in their chemical and mineralogical compositions. This is attributed to the fact that charcoal ash is a product of slow pyrolysis under limited oxygen conditions, and combustion under oxygenated conditions coupled with the volatilization of constituents in contrast to firewood ash which is the product of a onetime combustion of wood in its natural form under oxygenated conditions. This was reflected in higher $\mathrm{pH}, \mathrm{EC}$, and CCE in the charcoal ash in contrast to firewood ash. The $\mathrm{pH}$ values obtained for the firewood ash are similar to those found in Rwandan ashes from eucalyptus wood-dominated charcoal and firewood collected over a 3-month period (Neina, unpublished data). Similarly, a pH of 13.8 in a mix of firewood and charcoal were found in ashes from Accra, Ghana [4], while a range of 9-13.5 has also been obtained elsewhere $[5,7]$.

The EC values were close to those of $59 \mathrm{dS} \mathrm{m}^{-1}$ found in a mix of wood and charcoal ashes collected from Accra [4]. Similarly, an EC value of $50 \mathrm{dS} \mathrm{m}^{-1}$ in ash from a kraft pulp mill in the US [8]. This contrasts EC values of $3.1 \mathrm{dS} \mathrm{m}^{-1}$ from the combustion of biomass of only one tree species [5], which may have been different for ashes from different species. Then, the CCE values also fall within the range found by many authors [6-8]. Overall, the $\mathrm{pH}, \mathrm{EC}$, and $\mathrm{CCE}$ values have been associated with the alkali and alkaline earth metals in the ashes which often dominate ashes because of their high vaporization temperatures $[23,24]$. Presumably, this change in $\mathrm{pH}$ is coupled with changes in ash composition caused by the effects of combustion temperature aside the influence of biomass type and source. For instance, Qian et al. [24] found sharp ash $\mathrm{pH}$ increases with temperature from $\mathrm{pH}$ 4.9 at $250{ }^{\circ} \mathrm{C}$ to $\mathrm{pH} 10$ at $450{ }^{\circ} \mathrm{C}$, during a study on the effects of burn temperature on ash nutrient forms and availability from cattail (Typha domingensis Pers.) and sawgrass (Cladium jamaicense Crantz) in the Florida 
Table 3 Element-specific correlation matrix

\begin{tabular}{|c|c|c|c|}
\hline & $\mathrm{H}_{2} \mathrm{SO}_{4}$ & Vinegar & Water \\
\hline \multicolumn{4}{|l|}{$\mathrm{Ca}$} \\
\hline Aqua regia & 0.07 & $0.68^{* *}$ & 0.15 \\
\hline $\mathrm{H}_{2} \mathrm{SO}_{4}$ & & 0.26 & 0.16 \\
\hline Vinegar & & & $0.34^{*}$ \\
\hline \multicolumn{4}{|l|}{ K } \\
\hline Aqua regia & $0.68^{* * *}$ & $0.50^{* *}$ & $0.69^{* * *}$ \\
\hline $\mathrm{H}_{2} \mathrm{SO}_{4}$ & & $0.61^{* * *}$ & $0.73^{* * *}$ \\
\hline Vinegar & & & $0.55^{* * *}$ \\
\hline \multicolumn{4}{|l|}{$\mathrm{Mg}$} \\
\hline Aqua regia & $0.92^{* * *}$ & $0.84^{* * *}$ & 0.04 \\
\hline $\mathrm{H}_{2} \mathrm{SO}_{4}$ & & $0.87^{* * *}$ & -0.01 \\
\hline Vinegar & & & -0.03 \\
\hline \multicolumn{4}{|l|}{$\mathrm{Na}$} \\
\hline Aqua regia & $0.72^{* * *}$ & -0.22 & $0.84^{* * *}$ \\
\hline $\mathrm{H}_{2} \mathrm{SO}_{4}$ & & 0.55 & $0.72^{* * *}$ \\
\hline Vinegar & & & -0.09 \\
\hline \multicolumn{4}{|l|}{ P } \\
\hline Aqua regia & $0.87^{* * *}$ & $0.49^{* *}$ & -0.04 \\
\hline $\mathrm{H}_{2} \mathrm{SO}_{4}$ & & $0.57^{* * *}$ & 0.00 \\
\hline Vinegar & & & 0.06 \\
\hline \multicolumn{4}{|l|}{ *** $P<0.001$} \\
\hline \multicolumn{4}{|l|}{$* * P<0.01$} \\
\hline${ }^{*} P<0.05$ & & & \\
\hline
\end{tabular}

Everglades. In contrast, the $\mathrm{pH}$ increase was from 450 to $550{ }^{\circ} \mathrm{C}[24]$.

\section{Elemental composition}

Apart from the $\mathrm{pH}, \mathrm{EC}$, and CCE, the analysis of nutrient elements and trace element contents also suggested that firewood ash had higher $\mathrm{As}, \mathrm{Cu}, \mathrm{Mg}$, and $\mathrm{Zn}$ contents than its counterpart. Arsenic and $\mathrm{Cu}$ were found in smaller amounts while $\mathrm{Zn}$ was among the four trace elements $(\mathrm{Mn}, \mathrm{Ni}, \mathrm{Pb}$, and $\mathrm{Zn}$ ) which occurred in the order of hundreds. This corroborates the findings on bottom and fly ashes $[25,26]$. These elements are the most prevalent trace elements in some soils of Ghana [27], which might the reason for their prevalence in the ashes. This, however, contradicts the findings on bottom and fly ashes of Municipal solid wastes [28]. The amounts of elements extracted by the extractants were in the order, vinegar $>$ aqua regia $>\mathrm{H}_{2} \mathrm{SO}_{4}>$ water whereas that of specific elements extracted occurred in the order $\mathrm{Ca}>\mathrm{K}>\mathrm{Mg}>\mathrm{Na}>\mathrm{P}$ for both ashes. This contrasts the results of others $[14,29,30]$ who found the order $\mathrm{Ca}>\mathrm{Mg}>\mathrm{K}>\mathrm{Na}$. It is obvious from the relationships that aqua regia and vinegar are suitable for $\mathrm{Ca}$; acidic extractants for Mg; aqua regia and $\mathrm{H}_{2} \mathrm{SO}_{4}$ for $\mathrm{P}$ and $\mathrm{H}_{2} \mathrm{SO}_{4}$ and almost all the solutions vinegar for $\mathrm{K}$ and $\mathrm{Na}$ (Table 2).
Higher contents of $\mathrm{Ca}$ have been reported in previous studies on ashes [9, 22, 31]. Calcium and Mg minerals have been found in many studies on bottom and fly ashes [9, 22, 25]. Potassium followed $\mathrm{Ca}$ and agrees with results of Misra et al. [29]. Earlier studies by Neina and Dowuona [3] showed that water-soluble K constituted $43 \%$ of the acid-extractable K. In ashes generated from open combustion systems, $\mathrm{K}$ and $\mathrm{Na}$ are mostly watersoluble [5, 24]. Many ashes are a source of $K$ in the form of potash or alkali for local soap making and for cooking in many African countries [32-34].

\section{Mineralogical composition}

The mineral compounds found in the ashes are the basis for their composition revealing the differences between charcoal and firewood. This is reflected in more mineral compounds in firewood ash. These differences can be attributed to the effects of combustion temperature as earlier noted $[24,35,36]$. This lead to the increase of less volatile components [24] producing marked differences in the mineral constituents. During combustion, decomposition and volatilization occur and are mostly responsible for the disappearance [29] of ash constituents such as $\mathrm{CaCO}_{3}, \mathrm{CaO}$, As, $\mathrm{Cd}, \mathrm{Pb}, \mathrm{Hg}$, and $\mathrm{Zn}[30,37,38]$. Decomposition of hydroxides of $\mathrm{Ca}$ and $\mathrm{Mg}$, and $\mathrm{CaCO}_{3}$ has been found to occur at temperatures of $350-450{ }^{\circ} \mathrm{C}$ and $500-600{ }^{\circ} \mathrm{C}$, respectively [39]. At pyrolysis temperatures of $\left(500-800{ }^{\circ} \mathrm{C}\right)[39,40], \mathrm{CaCO}_{3}$ and $\mathrm{K}_{2} \mathrm{Ca}\left(\mathrm{CO}_{3}\right)_{2}$ dominate $[29,39]$ along with a soluble alkalinity, which decreases between 800 and $1000{ }^{\circ} \mathrm{C}$ [39]. Volatilization may have reduced contents of $\mathrm{Mg}, \mathrm{As}, \mathrm{Cu}, \mathrm{Zn}$, and the range of minerals compounds in the charcoal ash.

Aside from the effect combustion temperature, oxic or anoxic conditions play a role in ash composition. This could have resulted in the presence of many oxide minerals in the firewood ash, which is a product of direct combustion under oxic conditions. For the charcoal ash, the first step of combustion involves slow pyrolysis at temperatures between 400 and $500{ }^{\circ} \mathrm{C}[40,41]$ followed by combustion under oxic conditions of varying extents depending the kind of stove used. For instance, in Ghana, charcoal is either burnt in clay and metal cooking stoves of different forms, shapes, and sizes, which may affect the oxygen supply during the combustion and subsequently the ash composition. Another factor that may play a role in ash composition is the presence of $\mathrm{Si}, \mathrm{Mn}, \mathrm{Fe}, \mathrm{Al}$ which can readily form acidic oxides [29]. In some cases, new minerals such as portlandite can be formed when ash is wetted [22]. In some of the firewood ashes, the food vendors used water to quench the ambers before collecting the ash. This could be the source of portlandite in ashes.

There may be concerns over the magnitude of $\mathrm{Mn}, \mathrm{Ni}$, $\mathrm{Pb}$, and $\mathrm{Zn}$, there seems to be a threshold application rate 
Table 4 Heat map for the occurrence in percent of crystalline compounds found in charcoal and firewood ash from five cities in southern Ghana, as determined by powder $\mathbf{X}$-ray diffraction

\begin{tabular}{|c|c|c|}
\hline Mineral [Chemical formula] & Charcoal & Firewood \\
\hline \multicolumn{3}{|l|}{ Aluminum Oxide $\left[\mathrm{Al}_{2} \mathrm{O}_{3}\right]$} \\
\hline \multicolumn{3}{|l|}{ Ankerite $\left[\mathrm{Ca}(\mathrm{Mg}, \mathrm{Fe})\left(\mathrm{CO}_{3}\right)_{2}\right]$} \\
\hline \multicolumn{3}{|l|}{ Ankerite $\left[\mathrm{Ca}\left(\mathrm{Mg}_{0.67} \mathrm{Fe}_{0.33}\right)\left(\mathrm{CO}_{3}\right)_{2}\right]$} \\
\hline \multicolumn{3}{|l|}{ Calcite $\left[\mathrm{CaCO}_{3}\right]$} \\
\hline \multicolumn{3}{|l|}{ Calcium manganate $\left[\mathrm{CaMnO}_{3}\right]$} \\
\hline \multicolumn{3}{|l|}{ Calcium manganese oxide $\left[\mathrm{CaMnO}{ }_{2.98}\right]$} \\
\hline \multicolumn{3}{|l|}{ Calcium manganese oxide $\left[\mathrm{CaMnO}{ }_{2.95}\right]$} \\
\hline \multicolumn{3}{|l|}{ Carbonate apatite $\left[\mathrm{Ca}_{10}\left(\mathrm{PO}_{4}\right)_{3}\left(\mathrm{CO}_{3}\right)\right]$} \\
\hline \multicolumn{3}{|l|}{ Calcium oxide $[\mathrm{CaO}]$} \\
\hline \multicolumn{3}{|l|}{ Diopside $\left[\mathrm{CaMgO}_{6} \mathrm{~S}_{\mathrm{i} 2}\right]$} \\
\hline \multicolumn{3}{|l|}{ Dolomite $\left[\mathrm{Ca}\left(\mathrm{Ca}_{0.17} \mathrm{Mg}_{0.83}\right)\left(\mathrm{CO}_{3}\right)_{2}\right]$} \\
\hline \multicolumn{3}{|l|}{ Kutnahorite $\left[(\mathrm{Ca}, \mathrm{Mn})\left(\mathrm{CO}_{3}\right)_{2}\right]$} \\
\hline \multicolumn{3}{|l|}{ Merwinite $\left[\mathrm{Ca}_{3} \mathrm{Mg}\left(\mathrm{SiO}_{4}\right)_{2}\right]$} \\
\hline \multicolumn{3}{|l|}{ Mg-rich calcite $\left[\left(\mathrm{Mg}_{0.03} \mathrm{Ca}_{0.97}\right)\left(\mathrm{CO}_{3}\right)\right]$} \\
\hline \multicolumn{3}{|l|}{ Nickel manganese oxide $\left[\mathrm{Mn}_{0.2} \mathrm{Ni}_{7.6} \mathrm{O}_{8}\right]$} \\
\hline \multicolumn{3}{|l|}{ Periclase $[\mathrm{MgO}]$} \\
\hline \multicolumn{3}{|l|}{ Portlandite $\left[\mathrm{Ca}(\mathrm{OH})_{2}\right]$} \\
\hline \multicolumn{3}{|l|}{$\alpha$-Quartz $\left[\mathrm{SiO}_{2}\right]$} \\
\hline \multicolumn{3}{|l|}{$\beta$-Quartz $\left[\mathrm{SiO}_{2}\right]$} \\
\hline \multicolumn{3}{|l|}{ Sylvite $[\mathrm{KCl}]$} \\
\hline Zinc manganese oxide $\left[\mathrm{Zn}\left(\mathrm{Mn}_{2} \mathrm{O}_{4}\right)\right]$ & & \\
\hline
\end{tabular}

\begin{tabular}{|l|l|l|l|l|l|}
\hline $0 \%$ & $20 \%$ & $40 \%$ & $60 \%$ & $80 \%$ & $100 \%$ \\
\hline
\end{tabular}

beyond, which the elements may accumulate in plants [5, 42]. The accumulation of trace elements in plants is often associated with increased ash application $[5,43]$. Nevertheless, soil $\mathrm{pH}$ has been found to be the main determinant of element leaching and uptake [43]. Nonetheless, this creates another opportunity for further research on the threshold trace element contents of wood ash and their relationship with plant uptake in different soil $\mathrm{pH}$ and soil types. This study was designed as a start-up for future agronomic and microbial studies in the field. Therefore, the uptake of the trace elements by plants and soil microorganisms cannot be determined in the current study as this process is strongly affected by plant species and variety, soil $\mathrm{pH}$ and soil solution chemistry.

\section{Conclusions}

The mineralogical composition of the ash types will give important information on their future behavior as fertilizer in soil. The charcoal ash had higher pH, EC, $\mathrm{CCE}$ and $\mathrm{K}$, whereas the firewood ash contained more minerals and had higher $\mathrm{As}, \mathrm{Cu}, \mathrm{Mg}$, and $\mathrm{Zn}$ contents.
However, the differences in the ash compositions may not dictate which of them will make a better fertilizer supplement for UPA. Therefore, these ashes could be an important source of $\mathrm{K}$ for root or carbohydrate-rich crops. This study revealed that charcoal ash had higher $\mathrm{CCE}, \mathrm{EC}, \mathrm{pH}$, and $\mathrm{P}$ and $\mathrm{K}$ contents, whereas the firewood ash had more minerals with $86 \%$ containing $\mathrm{Mg}$, and higher contents of $\mathrm{As}, \mathrm{Cu}, \mathrm{Mg}$ and $\mathrm{Zn}$ than the charcoal ash. However, the trace element contents were usually below allowable limits required for ash application as fertilizers except for poorly soluble $\mathrm{Pb}$ and $\mathrm{Ni}$. Aqua regia and vinegar are suitable for $\mathrm{Ca}$, all solutions for $\mathrm{K}$, the "stronger acids" and water for $\mathrm{Na}$, all acids for $\mathrm{Mg}$ and aqua regia and $\mathrm{H}_{2} \mathrm{SO}_{4}$ for P. This study is not meant to promote biomass energy use but to harness plant nutrients present in ash wastes produced as part of municipal solid wastes and encourage its utilization in agriculture thus reducing the amount of wastes for disposal and also recycle as many nutrients as possible in the ecosystem. 


\section{Abbreviations}

AR: aqua regia; CCE: calcium carbonate equivalence; CEC: cation exchange capacity; EC: electrical conductivity; GEC: Ghana Energy Commission; LPG: liquefied petroleum gas; SA: sulfuric acid; UPA: urban and peri-urban agriculture; XRD: X-ray powder diffraction.

\section{Acknowledgements}

We are also indebted to Dr. Martin Egblewogbe and Miss. Beatrice Agyapomah for conducting the X-ray diffraction, to Mr. Ransford Okley Tetteh and Miss. Beatrice Kudavor for helping in the ash sampling, the technical support of Mr. Adusei Okrah and the laboratory staff of the Department of Soil Science, Mr. Prince Boateng of the Ecological Laboratory (Ecolab), University of Ghana, and Mr. Mario Boateng of the Department of Marine Science (Marine Laboratory), University of Ghana.

\section{Authors' contributions}

ND conceived, designed the study with the support of RGJ and collected the data; ND, RGJ and SF analyzed and interpreted the data; ND drafted the manuscript and revised it; RGJ and SF reviewed the manuscript. All authors read and approved the final manuscript.

\section{Funding}

We wish to acknowledge the financial support of the University of Kassel Strategic Research Fund for supporting this research.

\section{Availability of data and materials}

All data generated or analyzed during this study are included in this published article.

\section{Ethics approval and consent to participate}

Not applicable.

\section{Consent for publication}

Not applicable.

\section{Competing interests}

The authors declare that they have no competing interests.

\section{Author details}

${ }^{1}$ Department of Soil Science, School of Agriculture, University of Ghana, P.O. Box LG 245, Legon, Accra, Ghana. ${ }^{2}$ Soil Biology and Plant Nutrition, University of Kassel, Nordbahnhofstr. 1a, 37213 Witzenhausen, Germany.

\section{Received: 13 August 2019 Accepted: 11 November 2019}

Published online: 05 March 2020

\section{References}

1. Park BB, Yanai RD, Sahm JM, Ballard BALPD. Wood ash effects on soil solution and nutrient budgets in a willow bioenergy plantation. Water Air Soil Pollut. 2004;159:209-24.

2. Pasquini MW, Alexander MJ. Chemical properties of urban waste ash produced by open burning on the Jos Plateau: implications for agriculture. Sci Total Environ. 2004;319:225-40.

3. Neina D, Dowuona GNN. Short-term effects of human urine fertiliser and wood ash on soil pH and electrical conductivity. J Agric Rural Dev Trop. 2013;114:89-100

4. Merino A, Otero V, Omil B, Lastra B, Piñeiro V, Gallego PP. Application of wood ash compared with fertigation for improving the nutritional status and fruit production of kiwi vines. J Plant Nutr Soil Sci. 2006:169:127-33.

5. Nabeela F, Murad W, Khan I, Mian IA, Rehman H, Adnan M, Azizullah A. Effect of wood ash application on the morphological, physiological and biochemical parameters of Brassica napus L. Plant Physiol Biochem. 2015;95:15-25.

6. Ohno T, Erich MS. Effect of wood ash application on soil pH and soil test nutrient levels. Agric Ecosyst Environ. 1990;32:223-39.

7. Demeyer A, Voundi Nkana JC, Verloo MG. Characteristics of wood ash and influence on soils properties and nutrient uptake: an overview. Bioresour Technol. 2001;77:287-95.
8. Patterson SJ, Acharya SN, Thomas JE, Bertschi AB, Rothwell RL. Barley biomass and grain yield and canola seed yield response to land application of wood ash. Agron J. 2004:96:971-7.

9. Lanzerstorfer C. Chemical composition and physical properties of filter fly ashes from eight grate-fired biomass combustion plants. J Environ Sci. 2015;30:191-7.

10. Arvidsson $H$, Lundkvist $H$. Effects of crushed wood ash on soil chemistry in young Norway spruce stands. For Ecol Manag. 2003;176:121-32.

11. Kalmykova Y, Karlfeldt FK. Phosphorus recovery from municipal solid waste incineration fly ash. Waste Manag. 2013;33:1403-10.

12. Rey-Salgueiro L, García-Falcón MS, Soto-González B, Simal-Gándara J. Procedure to measure the level of polycyclic aromatic hydrocarbons in wood ashes used as fertilizer in agroforestry soils and their transfer from ashes to water. J Agric Food Chem. 2004;52:3900-4.

13. Pérez-Gregorio MR, García-Falcón MS, Martínez-Carballo E, Simal-Gándara J. Removal of polycyclic aromatic hydrocarbons from organic solvents by ashes wastes. J Hazard Mater. 2010;178:273-81.

14. Zhang FS, Yamasaki S, Nanzyo M. Waste ashes for use in agricultural production: I. Liming effect, contents of plant nutrients and chemical characteristics of some metals. Sci Total Environ. 2002;284:215-25.

15. UNDP. The energy access situation in developing countries: a review focusing on the Least Developed Countries and sub-Saharan Africa. Environment and Energy Group, United Nations Development Programme, New York, USA; 2009

16. Kebede E, Kagochi J, Jolly CM. Energy consumption and economic development in Sub-Sahara Africa. Energy Econ. 2010;32:532-7.

17. GEC. Ghana Energy Commission, strategic national energy plan 2006-2020, annex one of four. 2006. https://www.energycom.gov.gh/ files/snep/ENERGY\%20DEMAND\%20final\%20PD.pdf. Accessed 20 Dec 2015.

18. GEC. Ghana Energy Commission, national energy statistics 2009-2018. Strategic planning and policy directorate. 2019. https://www.energycom. gov.gh/files/ENERGY STATISTICS-2019.pdf. Accessed 21 Oct 2019

19. Kwakwa PA, Wiafe ED, Alhassan $\mathrm{H}$. Households energy choice in Ghana. Empir Econ. 2013;1:96-103.

20. FAO. Profitability and sustainability of urban and peri-urban agriculture. Agricultural management, marketing and finance occasional paper 19. Food and Agriculture Organization of the United Nations, Viale delle Terme di Caracalla, 00153 Rome, Italy 19; 2007. xii:95.

21. Obuobie E, Keraita B, Danso G, Amoah P, Cofie OO, Raschid-Sally L, Drechsel P. Irrigated urban vegetable production in Ghana: characteristics, benefits and risks: IWMI-RUAF-CPWF, Accra, Ghana: IWMI; 2006. p. 150. https://ageconsearch.umn.edu/bitstream/137958/2//rrigated_Urban _Vegetable_Production_in_Ghana.pdf.

22. Holmberg SL, Claesson T. Mineralogy of granulated wood ash from a heating plant in Kalmar Sweden. Environ Geol. 2001;40:820-8.

23. Valmari T. Potassium behaviour during combustion of wood in circulating fluidised power plants. Ph.D. Thesis, Helsinki University of Technology, Finland; 2000.

24. Qian Y, Miao SL, Gu B. Effects of burn temperature on ash nutrient forms and availability from cattail (Typha domingensis) and Sawgrass (Cladium jamaicense) in the Florida Everglades. J Environ Qual. 2009;38:451-64.

25. Dahl O, Nurmesniemi H, Pöykiö R, Watkins G. Heavy metal concentrations in bottom ash and fly ash fractions from a large-sized (246 MW) fluidized bed boiler with respect to their Finnish forest fertilizer limit values. Fuel Process Technol. 2010;91:1634-9.

26. Nurmesniemi H, Mäkelä M, Pöykiö R, Manskinen K, Dahl O. Comparison of the forest fertilizer properties of ash fractions from two power plants of pulp and paper mills incinerating biomass-based fuels. Fuel Process Technol. 2012;104:1-6.

27. Eze PN, Udeigwe TK, Stietiya MH. Distribution and potential source evaluation of heavy metals in prominent soils of Accra Plains. Ghana. Geoderma. 2010;156:357-62.

28. Zhao Y. Pollution control and resource recovery: municipal solid wastes incineration: bottom ash and fly ash. Amsterdam: Elsivier; 2016.

29. Misra MK, Ragland KW, Baker AJ. Wood ash composition as a function of furnace temperature. Biomass Bioenergy. 1993;4:103-16.

30. Sanders $M-L$, Andrén $O$. Ash from cereal and rape straw used for heat production: liming effects and contents of plant nutrients and heavy metals. Water Air Soil Poll. 1997:93:93-108. 
31. Emilsson S. International handbook—from extraction of forest fuels to ash recycling. Stockholm: Swedish Forest Agency, Jönköping; 2006.

32. Babayemi JO, Adewuyi GO, Obi-Egbedi NO. Evaluation of options in wood waste management: burning and consequent alkali production. J Sustain Dev Environ Prot. 2011;1:98-109.

33. Kuye $\mathrm{AO}$, Okorie $\mathrm{C}$. Factors affecting the lixiviation of palm bunch ash as a source of alkali for soap production. Ife J Technol. 1990;3:33-7.

34. Taiwoo OE, Osinowo FAO. Evaluation of various wastes for traditional black soap making. Biores Technol. 2001;79:95-7.

35. Ulery AL, Graham RC, Amrhein C. Wood-ash composition and soil pH following intense burning. Soil Sci Soc Am J. 1993;156:358-64.

36. Certini G. Effects of fire on properties of forest soils: a review. Oecologia. 2005;143:1-10.

37. Pacyna JM. Atmospheric emissions of arsenic, cadmium, lead and mercury from high temperature process in power generation and industry. In: Hutchinson TC, Meema KM, editors. Lead, mercury and arsenic in the environment. New York: Wiley; 1987. p. 69-87.

38. Gray DB, Watts F, Overcamp TJ. Volatility of arsenic in contaminated clay at high temperatures. Environ. Eng Sci. 2001;8:69-87.

39. Liodakis S, Katsigiannis G, Kakali G. Ash properties of some dominant Greek forest species. Thermochim Acta. 2005;437:158-67.
40. FAO. Integrated energy systems in China - the cold Northeastern region experience. 1994. https://www.fao.org/3/a-t4470e/t4470e0a.htm. Accessed 2 May 2017.

41. Seidel A. Charcoal in Africa: importance, problems and possible solution strategies. Household Energy Programme (HERA), Eschborn, Germany: German Technical Cooperation; 2008.

42. Pandey VC, Abhilash PC, Upadhyay RN, Tewari DD. Application of fly ash on the growth performance and translocation of toxic heavy metals within Cajanus cajan L.: implication for safe utilization of fly ash for agricultural production. J Hazard Mater. 2009;166:255-9.

43. Ram LC, Masto RE. Fly ash for soil amelioration: a review on the influence of ash blending with inorganic and organic amendments. Earth Sci Rev. 2014;128:52-74.

\section{Publisher's Note}

Springer Nature remains neutral with regard to jurisdictional claims in published maps and institutional affiliations.

\section{Submit your manuscript to a SpringerOpen ${ }^{\circ}$ journal and benefit from:}

- Convenient online submission

- Rigorous peer review

- Open access: articles freely available online

- High visibility within the field

- Retaining the copyright to your article

Submit your next manuscript at $\boldsymbol{\nabla}$ springeropen.com 